Ann. Phytopath. Soc. Japan XXX, (4) : 225 230 (1965)

\title{
Purification of rice dwarf virus
}

\section{Late Sakae Toyoda, Ikuo KIMurA, and Naoji SuzukI}

\section{Introduction}

Fukushi, Shikata, and Kimura ${ }^{1)}$ isolated characteristic virus-like particles, icosahedrons of $70 \mathrm{~m} \mu$ in diameter, from both rice dwarf virus (RDV)-infected rice plants and viruliferous leaf hoppers by differential centrifugation techniques. The same particles were present in the cells of infected rice plants and of viruliferous leafhoppers (Nephotettix cincticeps), sometimes aggregating into a crystal-like arrangement. Fukushi and Kimura ${ }^{2)}$ demonstrated that these particles were infective to the insect vector and also to rice plants, by injecting leafhoppers with particles and feeding them with rice seedlings. From these results, it is concluded that these particles are RDV. The electron micrographs given by these authors ${ }^{1)}$ show that the particles are enveloped with a membranaceous material. Later studies by Kimura et al. ${ }^{3,4}$ ) showed that RDV particles isolated by differential centrifugation techniques accompanying chloroform- and phospholipasetreatment possess hollow capsomeres which could possibly be visualized by removing the enveloping material with phospholipase treatment. Similar results were reported by Fukushi et al.5). by removing the enveloping material with ethylether treatment. The question still remains as to whether the enveloping material is the essential component of RDV or a contamination originating from host responses, and whether the particles present in infected rice plants are identical with those present in infected leafhoppers. Recent electron microscopic studies by Nasu ${ }^{6)}$ revealed that particles of a smaller size are present beside the typical RDV particles in viruliferous leaf hopper cells where the virus seems to be vigorously multiplying. Are these smaller particles a form of RDV appearing in the process of multiplication? Before answering these questions, further knowledge is required concerning morphological and chemical properties of RDV using purified virus. This paper reports the result of successful purification of RDV from infected rice plants, and the infectivity tests of the purified RDV.

\section{Materials and Methods}

The RDV isolate used in this study was kindly furnished by Dr. Akira Shinkai who preserved this isolate for past 16 years at the National Institute of Agricultural Sciences, Tokyo. The virus was cultured in rice variety, Norin No. 8. Leaves and leaf-sheaths showing apparent symptoms were harvested and $50 \mathrm{~g}$ of fresh weight was used for each purification experiment run. Finally, $300 \mathrm{~g}$ was used for the chromatographic separation of RDV employing step-wise elution with $\mathrm{NaCl}$.

Differential centrifugation: Fifty grams of infected leaves and leaf-sheaths were cut into small pieces, ground with the addition of 200 to $500 \mathrm{ml}$ of $\mathrm{M} / 30$ phosphate buffer, $\mathrm{pH} 6.8$, then the sap was expressed through cheese cloth and centrifuged at $6,500 x$ for 30 minutes. The top layer was stirred with 10 or 20 per cent volume of chloroform for 5 minutes and centrifuged at $1,600 \mathrm{xg}$ for 20 minutes. The supernatant was centrifuged at $26,000 \mathrm{xg}$ for 60 minutes. Aftrr removing the supernant, the pellet was suspended in $\mathrm{M} / 40$ tris buffer, $\mathrm{pH} 7.2$, and centrifuged

* National Institute of Agricultural Sciences, Nishigahara, Kitaku, Tokyo. 
at $1,600 \mathrm{xg}$ for 20 minutes. The supernatant (fraction A) consisted of high concentration of virus particles when examined under the electron microscope.

Treatment of fraction A with phospholipase: Phospholipase was prepared from snake venom* (Trimeresurus flavoviridis) and also from pancreatin. Five $\mathrm{mg}$ of venom was dissolved in $1 \mathrm{ml}$ of tris buffer, $\mathrm{pH} 7.2$, and treated in boilng water for 7 minutes, cooled, and centrifuged at 3,000 rpm for 15 minutes. The supernatant was used as crude phospholipase preparation. Five mg of venom was used for each $5 \mathrm{ml}$ of fraction A obtained from $50 \mathrm{~g}$ of infected leaves.

Phospholipase from pancreatin was prepared after Hanahan's method ${ }^{7)}$. Fifteen grams of pancreatin was dissolved in $100 \mathrm{ml}$ of $\mathrm{M} / 15$ phosphate buffer, $\mathrm{pH} 6.0$, stirred for 20 minutes at $4^{\circ} \mathrm{C}$, and centrifuged at $12,000 \mathrm{rpm}$ for 45 minutes. The supernatant was adjusted to $\mathrm{pH} 4.0 \mathrm{with}$ dil. $\mathrm{HCl}$, treated at $70^{\circ} \mathrm{C}$ for 10 minutes, cooled, and centrifuged at $3,000 \mathrm{rpm}$ for 10 minutes. The supernatant was used as crude phospholipase preparation. Three $\mathrm{ml}$ of the enzyme preparation was used for treating $50 \mathrm{ml}$ of fraction A obtained from $300 \mathrm{~g}$ of infected leaves.

Fraction $\mathrm{A}$ was incubated with phospholipase at $5^{\circ} \mathrm{C}$ for 48 hours, centrifuged at $26,000 \mathrm{xg}$ for 60 minutes, the precipitate being suspended in $5 \mathrm{ml}$ or $50 \mathrm{ml}$ of phosphate or tris buffer (fraction B). Tris buffer is more suitable than phosphate buffer for the following steps of purification using column chromatography.

Column chromatography: Column chromatography by the use of DEAE-cellulose (Brown Co., $0.93 \mathrm{meq} / \mathrm{g}$ ) was applied for the separation of RDV from fraction B. Five $\mathrm{g}$ of DEAE-cellulose was used for each $5 \mathrm{ml}$ of fraction $\mathrm{B}$ obtained from $50 \mathrm{~g}$ of infected leaves. The DEAE-cellulose column was conditioned by washing with distilled water, $\mathrm{N} \mathrm{NaOH}$, and again with enough amount of distilled water until the $\mathrm{pH}$ of effluent fell to 7.2. The column, to which fraction $\mathrm{B}$ had been added, was washed with 50 to $100 \mathrm{ml}$ of $\mathrm{M} / 40$ tris buffer, $\mathrm{pH} \mathrm{7.2,} \mathrm{and} \mathrm{then} \mathrm{with} \mathrm{tris} \mathrm{buffer}$ mixed with linear gradient of $\mathrm{NaCl}$ from 0 to $1.0 \mathrm{M}$, using two-jar arrangement as the mixing device. The presence of virus in each $5 \mathrm{ml}$ of effluent was examined by measuring the optical density at $260 \mathrm{~m} \mu$. After it was confirmed that the virus would be eluted at a definite range of $\mathrm{NaCl}$ concentration, step-wise elution method was adopted to step up the purification procedure from larger amount of infected leaves.

Electron microscopy: Drops of fraction A, B, and every $5 \mathrm{ml}$ of the effluent showing high optical density at $260 \mathrm{~m} \mu$ were placed on carbon-coated grids. The grids were shadowed with chromium or platinum, or negatively stained with phosphotungustate and micrographs were taken with Hitachi H.U. -11 electron microscope.

\section{Results}

\section{Column chromatography of fraction $A$}

The DEAE-cellulose column chromatography of fraction A (Fig. 1-A) showed that only a very small amount of virus was eluted with $\mathrm{NaCl}$ ranging from 0.2 to $0.25 \mathrm{M}$, while a much larger amount was firmly adsorbed by DEAE - cellulose without being eluted with $\mathrm{NaCl}$ at higher concentration up to $1.0 \mathrm{M}$ and was eluted only with $0.5 \mathrm{M} \mathrm{NaOH}$. This suggests that the virus particles are covered with some strongly acidic substance, presumably the enveloping material shown by Fukushi et al. ${ }^{1}$. The treatment of fraction $\mathrm{A}$ with 0.5 per cent sodium deoxycholate for 3 hours at $5^{\circ} \mathrm{C}$ showed no marked change in the chromatographic feature as shown in Fig. $1-\mathrm{B}$, whereas the incubation of fraction $\mathrm{A}$ at $5^{\circ} \mathrm{C}$ for five days greatly faciliated the elution of virus with $\mathrm{NaCl}$ at low concentrations as shown in Fig. 1-C. Electron micrographs of effluents

\footnotetext{
* The venom was kindly supplied by Dr. T. Omura, Protein Institute, Osaka University.
} 
at 0.2 to $0.25 \mathrm{M} \mathrm{NaCl}$ showed that these contained a large amount of typical RDV particles. This may be caused by some impurity which is presumably an enzyme originating from host plants and is able to decompose the enveloping mateiral.

\section{Column chromatography of fraction $B$}

The enveloping material seems to be a lipid from its appearance in the electron micrograph shown by Fukushi et al. ${ }^{1)}$, and is strongly acidic from the result of DEAE-cellulose column chromatography. Phosphorus was actually detected in the chloroform-methanol extract of the dried fraction A. These results suggest that the enveloping material may be a phospholipid.

Fraction B was obtained by treating fraction $A$ with snake venom phospholipase as already described. The DEAE-cellulose column chromatograph of this fraction is shown in Fig. 2-A.

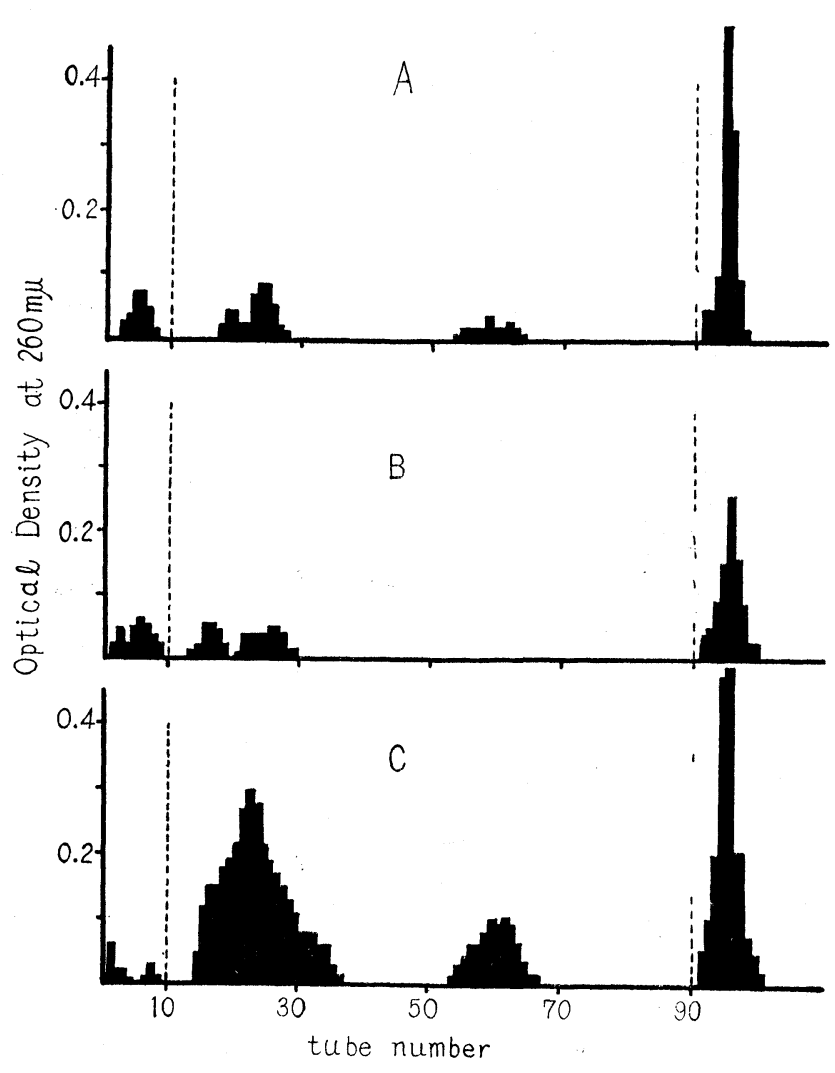

Fig. 1. DEAE-cellulose column chromatography of fraction $A$.

A. Fraction A.

B. Fraction A after treatment with $0.5 \%$ sodium deoxycholate for 3 hours at $5^{\circ} \mathrm{C}$.

C. Fraction A after 5-day incubation at $5^{\circ} \mathrm{C}$.

The control, using healthy rice leaves, is shown in Fig. 2-B. The peak appearing at about $0.2 \mathrm{M} \mathrm{NaCl}$ in Fig. 2-A is characteristic to fraction $\mathrm{B}$ as compared with the chromatographs of fraction A (Fig. 1-A) and the control of fraction B (Fig. 2-B). The effluent corresponding to this peak contained a large amount of typical RDV particles when examined under electron microscope.

\section{Column chromatography of fraction $B$ by step-wise elution}

Fraction B, $50 \mathrm{ml}$., was prepared from $300 \mathrm{~g}$ fresh weight of infected leaves by the same procedure described above except that pancreatin-phsopholipase was used in place of snake venom. phospholipase. Ten $\mathrm{ml}$ of the fraction was added to a column containing $6 \mathrm{~g}$ of DEAE-cellulose. The column was washed with $200 \mathrm{ml}$ of $0.15 \mathrm{M} \mathrm{NaCl}$, then $\mathrm{RDV}$ was eluted with $0.25 \mathrm{M} \mathrm{NaCl}$. Every $20 \mathrm{ml}$ of the effluent was taken in a test tube and the optical density at $260 \mathrm{~m} \mu$ was determined. The result is shown in Fig. 3. The effluent collected from the 12 th and 13 th tubes was apparently a dense emulsion with opalescence. This was sedimented by centrifugation at $26,000 \times \mathrm{g}$ for 1 hour and the pellet was suspended in 5 or $\mathrm{ml}$ of distilled water (fraction C. ) 


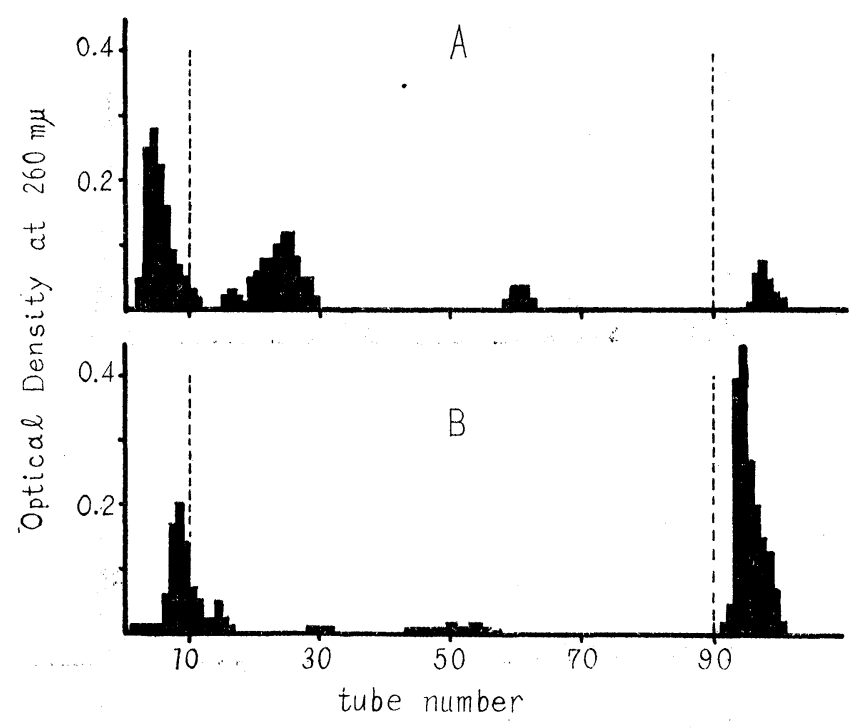

Fig. 2. DEAE-cellulose column chromatography of fraction $B$ which was prepared by treating fraction $A$ with phospholipase.

A.SFraction B from infected plants.

B. Control, from healthy plants.

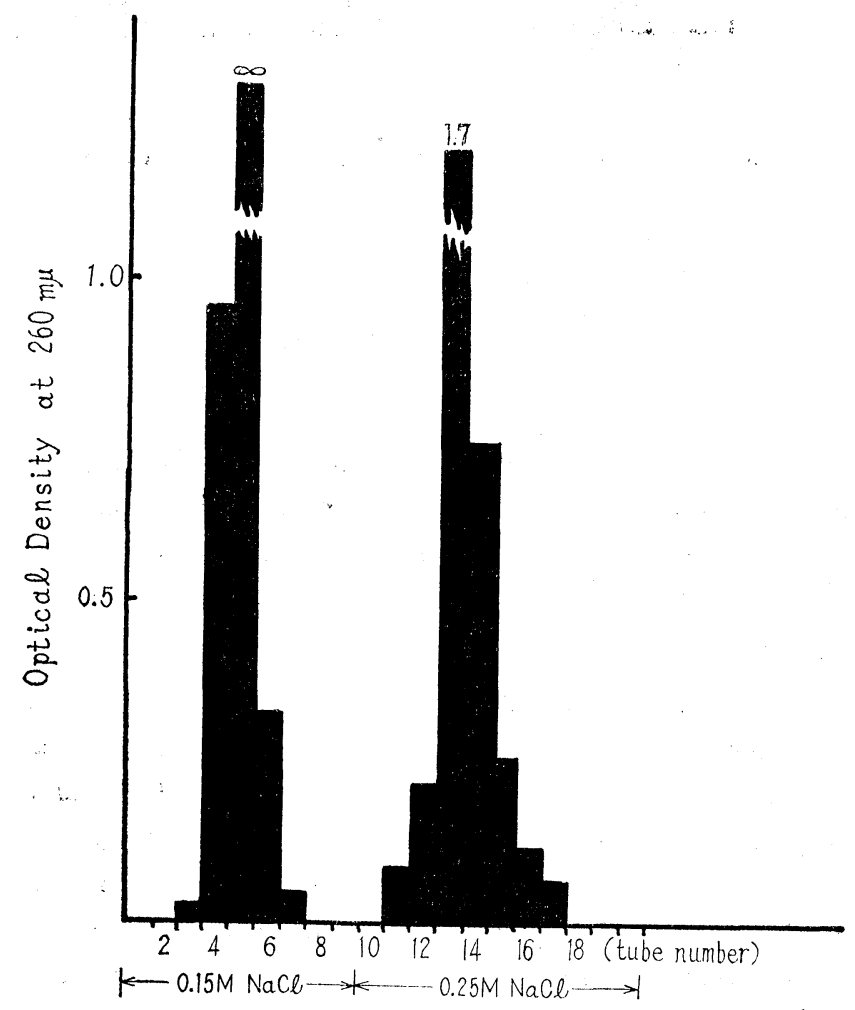

Fig. 3. DEAE-cellulose column chromatography of fraction $\mathrm{C}$ by step-wise elution method.

\section{Homogeneity of RDV} in fraction $\mathbf{C}$

The homogeneity of the virus in fraction $\mathrm{C}$ was examined by electrophoretic and sedimentation patterns. The results are shown in Figs. 4 and 5 . An electron micrograph of this fraction is shown in Fig. 6.

Both patterns clearly show that the virus in fraction $\mathrm{C}$ is highly homogeneous. Small peaks on both patterns are due to the disintegration product of the virus itself, nucleic acid and empty shells respectively, appearing during the short period of suspending the virus in tris buffer or distilled water (Figs. $7,8)$.

The electron micrograph of the shadowed sample of this fraction $\mathrm{C}$ shows that that this consists of highly concentrated RDV particles (Fig. 6). The micrograph of negatively stained sample shows that the particles are entirely free from the enveloping material and the presence of capsomeres is visualized. (Fig. 7).

\section{Infectivity of the purified virus}

The infectivity of the virus in fraction $\mathrm{C}$ was tested indirectly by proving the transmission of virus from inoculated leafhoppers to rice seedlings. Each virus-free leafhopper was inoculated by injecting about $1 / 3000 \mathrm{ml}$ of fraction $\mathrm{C}$ : into its abdomen and was fed with a test rice seedling and the symptoms on rice seedlings were examined 
after 20 to 60 days. The results in Tables 1 and 2 show that the purified virus retains infectivity.

\section{Discussion}

The enveloping material of RDV particles shown by Fukushi et $a l^{1)}$. raised a question as to whether this was an essential component of RDV or a substance originating from host responses. The present study revealed that this is a strongly acidic substance and is easily removed by treating with crude phospholipase preparation from snake venom or pancreatin, suggesting that this is a kind of phospholipid. The amount of the material adhering to the virus particles varied according to the materials used for isolation of the virus, i. e., the amount was very large with infected rice $1 \epsilon \varepsilon \cdot$ !! which grew

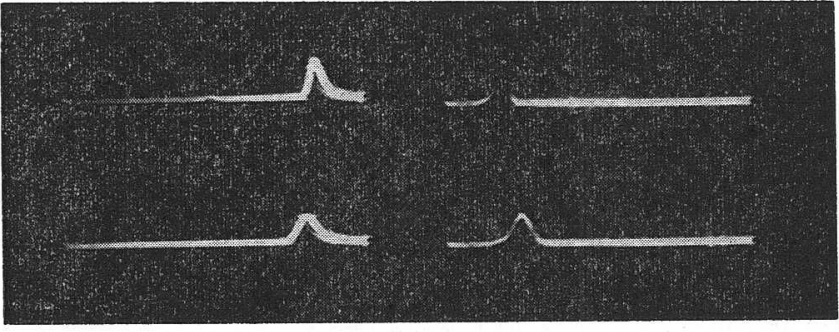

$\mathrm{r} \leftarrow$

Fig. 4. Electrophoretic patterns of fraction $\mathrm{C}$ in M/20 phosphate buffer of ionic strength 0.2 and $\mathrm{pH} 8.2$, after 1 (upper) and 2 (lower) hours. r: ascending, d: discending

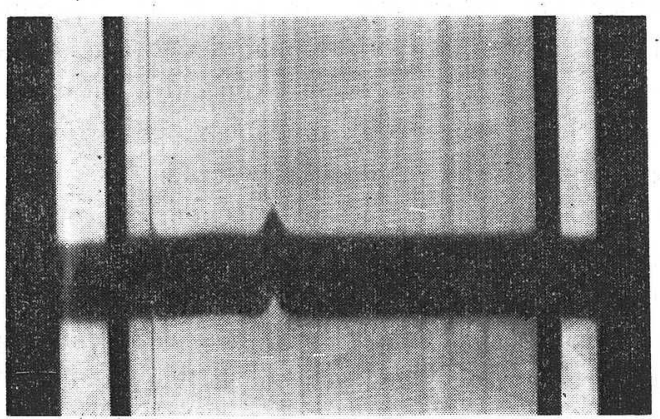

Fig. 5. Sedimentation pattern of fraction $\mathrm{C}$ in distilled water, after 4 minutes at 20,410 rpm by Spinco Model E. vigorously during midsummer, while it was almost negligible with rice leaves harvested in the cool autumn, so that there was no need of phospholipase treatment to elute the virus from DEAE-cellulose column. The infectivity test of the purified virus which had been freed from the enveloping material showed that the enveloping meterial was not essential for the infectivity.

Table 1. Infectivity tests made by injecting leafhoppers with the purified virus preparation and feeding them with test rice seedlings.

\begin{tabular}{c|c|c|c}
\hline \multirow{2}{*}{} & \multicolumn{3}{|c}{ Number of leafhoppers } \\
\cline { 2 - 4 } & inoculated & $\begin{array}{c}\text { survived for } \\
20 \text { days }\end{array}$ & $\begin{array}{c}\text { transmitted virus to } \\
\text { rice seedlings }\end{array}$ \\
\hline I & 60 & 28 & 7 \\
II & 60 & 21 & 4 \\
\hline
\end{tabular}

Table 2. Comparison of the infectivity of fractions A and C.

\begin{tabular}{c|c|c|c|c}
\hline \multirow{2}{*}{ Fraction } & \multicolumn{3}{|c|}{ Number of leafhoppers } & Virus content \\
\cline { 2 - 5 } & injected & $\begin{array}{c}\text { survived for } \\
20 \text { days }\end{array}$ & $\begin{array}{c}\text { transmitted } \\
\text { virus to } \\
\text { rice seedling }\end{array}$ & in fraction \\
\hline A & 60 & 22 & 5 & $3.06 \mathrm{mg} / \mathrm{ml}$ \\
C & 60 & 25 & 2 & $0.15 \mathrm{mg} / \mathrm{ml}$ \\
\hline
\end{tabular}


All these data indicate that the material is of host origin.

The electron micrographs shown by Fukushi et $a l^{1}$. indicate that the virus particles are arranged linearly in a bundle of sheaths in infected rice leaf cells. Recent electron microscopic studies by $\mathrm{Nasu}^{6)}$ on ultrastructure of the RDV-infected cells revealed that the virvus particles are arranged linearly in a long line within a sheath and the sheaths gather in a parallel arrangement, finally resulting in formation of crystal-like structure as shown previously by Fukushi et $a l^{1}$. The chemical nature of the enveloping material and its relationship to the sheath are still obscure.

\section{Summary .}

The electron micrograph of rice dwarf virus (RDV) given by Fukushi, Shikata, and Kimura ${ }^{1)}$ shows that RDV particles are enveloped with a membranaceous material. A fraction containing similar RDV particles was obtained from infected rice leaves by treating the expressed sap with 10 to 20 per cent chloroform and the same differential cenrifugation procedure as adopted by Fukushi $e t a l^{11}$. RDV in this fraction was so firmly adsorbed by DEAE-cellulose column that it could not be eluted with increasing concentration of $\mathrm{NaCl}$ from 0 to $1.0 \mathrm{M}$, but was eluted only with $0.5 \mathrm{M} \mathrm{NaOH}$, suggesting that the virus particles were covered with some strongly acidic substance, possibly the enveloping material. This material was easily removed by treating the fraction with phospholipase of snake venom or pancreatin. After this treatment, RDV was eluted from DEAE-cellulose column with 0.2 to $0.25 \mathrm{M} \mathrm{NaCl}$. $\mathrm{RDV}$ in the effluent showed typical morphological characteristics, an icosahedron with hollow capsomeres, when examined under electron microscope. Electrophoretic and sedimentation patterns of the effluent showed that the preparation consisted of homogeneous RDV particles. The purified RDV retained infectivity to rice plants when assayed through the insect vector, Nephotettix cincticeps Uhler.

(Received on April 10, 1965)

\section{Literature Cited}

1. Fukushi, T., Shikata, E., and Kimura, I. (1962). Virology $18: 192-205$.

2. Fukushi, T., and Kimura, I. (1959). Proc. Japan Acad. $35: 482-484$.

3. Kimura, I., Toyoda, S., and Suzuki, N. (1963). Ann. Phytopath. Soc. Japan $28: 85$ (abst.)

4. Kimura, I., Toyoda, S., and Suzuki, N. (1964). Ann. Phytopath. Soc. Japan $29: 72$ (abst.)

5. Fukushi, T., and Shikata, E. (1963). Virology $21: 500-503$.

6. Nasu, S. (1964). Personal communication.

7. Hanahan, D. J. (1952) J. Biol. Chem. $195: 199-206$.

\section{和文摘要}

\section{イネ萎絔病ウイルスの純化}

故豊田 栄**木村郁夫*·鈴木直治*

福士・四方・木村 ${ }^{1)}$ によイネ萎縮病ウイルスの電顕像はウイルス粒子が油滴状物質で被われていること を示している。罹病イネ茎葉から分画遠心分離で得たウイルス標品は DEAE セルローズカラムに吸着され $\mathrm{NaCl} 0 \sim 1 \mathrm{M}$ の濃度勾配で溶出されず，0.5 M NaOH でようやく溶出されるところからみて被覆物質は強 酸性物質と想像される。蛇毒特よびパンクレアチンのホスホリパーゼで $5^{\circ} \mathrm{C}, 2$ 日処理するとこの物質は完 全に除去され，ウイルス粒子は DEAE セルローズカラムから $0.2 \sim 0.25 \mathrm{M} \mathrm{NaCl}$ で溶出され，この溶出 液中のウイルス粒子は電気泳動像，沈降図型执よび電子顕微鏡観察から純度の高いことが示された。これを 無毒ツマグロヨコバイに注射すると、ヨコバイが保毒になりイネを発病させた。このことにより純化された ウイルスが感染力を有することが証明された。同じ方法で, $0.15 \mathrm{M} \mathrm{NaCl}$ 溶出部を唅て $0.25 \mathrm{M} \mathrm{NaCl}$ 溶 出部をとると同様のウイルス標品を得る。生葉 $300 \mathrm{~g}$ から約 $30 \mathrm{mg}$ のウイルスが得られる。

(*農業技術研究所) 

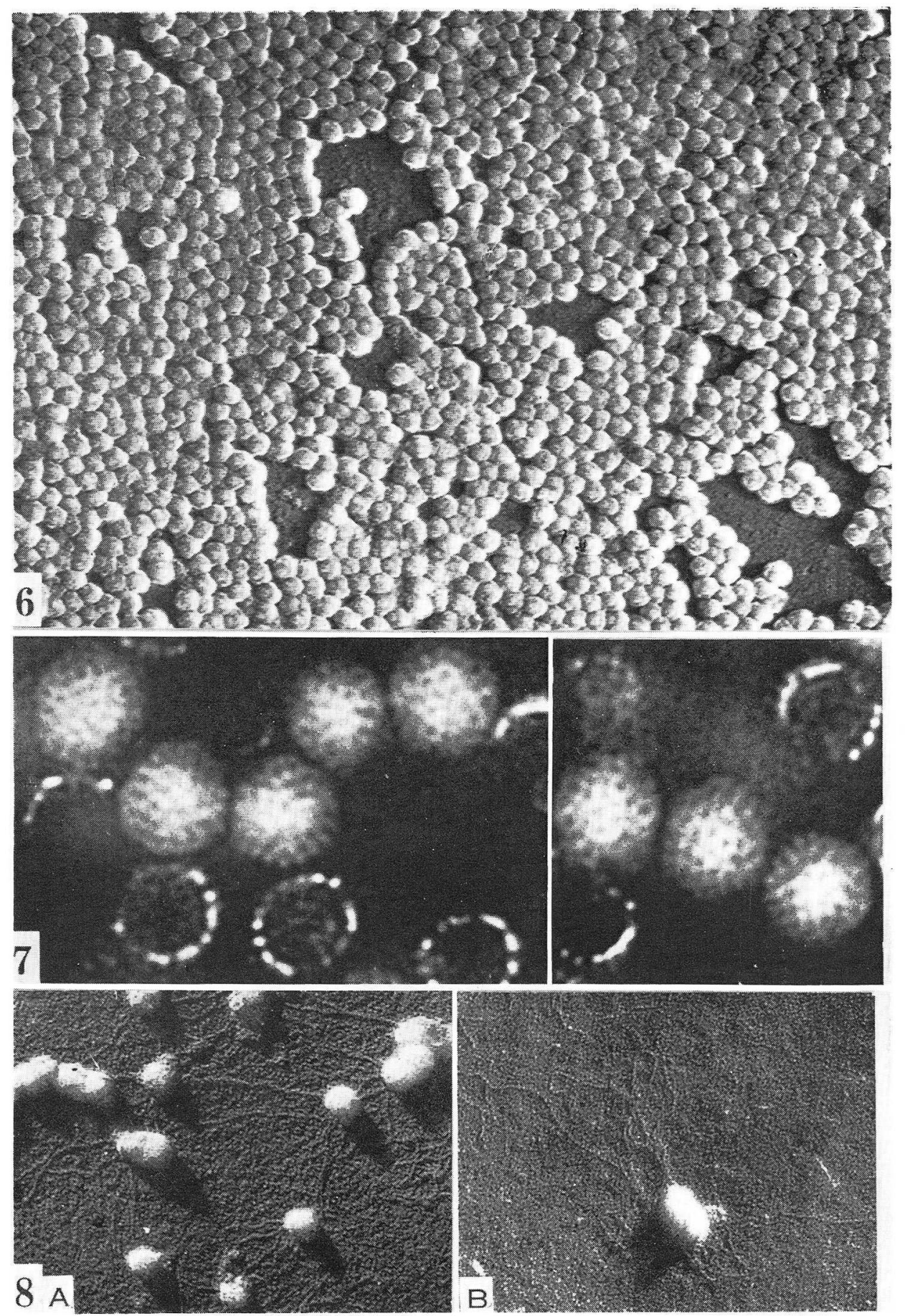

Fig. 6. Electron micrograph of fraction $\mathrm{C}$ shadowed with chromium.

Fig. 7. Electron micrograph of RDV particles in fraction $\mathrm{C}$ negatively stained with phosphotungustate, showing the presence of capsomeres on each particle and the contamination of empty shells after suspension in distilled water.

Fig. 8. Appearance of RNA-strands from virus particles after freezing followed by thawing ( $A$ ) and after suspending the virus in distilled water (B). 